\section{Borax as a Fertiliser}

Ir has long been known that a group of about ten elements plays an essential part in plant nutrition, but it is only during recent years that it has become recognised that other elements are of equal importance, though in such small amounts that their presence was previously unsuspected. Manganese and boron are the outstanding examples of these minor elements- 'minor' only in the sense that the requisite quantity is so small. Copper, zinc and other substances may also play an essential part in specific cases, and active research is in progress. The case with regard to boron is of definite economic importance. The pioneer work of Agulhon (1910) and Warington (1923) established the fact that in the entire absence of boron certain species, at least, are unable to develop properly. The necessary amount of boron is so small that most soils contain sufficient for the normal development of plants. During the last few years attention has been focused on certain obscure plant diseases for which no adequate explanation was forthcoming, and in many cases amelioration has been obtained by the application of boron compounds to the soil. Heart rot of sugar beet and brown heart of turnips are notable examples of this, and it is becoming a recognised practice to include a small quantity of boron compounds with the fertiliser, 12-20 lb. of borax per acre representing the safe limit, beyond which there is danger of injuring the plants by poisoning them. The great economic importance of this point has led to the establishment of a Boron Agricultural Bureau under the ægis of Borax Consolidated, Ltd., for the purpose of collecting and distributing information with regard to the use of borax for agricultural purposes. A word of warning may not be out of place. The beneficial results so far obtained by the application of borax as a specific against certain plant diseases may lead to undue optimism, and to a tendency to attribute every obscure plant disease to lack of boron, without adequate inquiry. The necessity for continued research must be emphasised, as it seems possible that the correct use of various 'minor' elements may lead to definite and valuable progress in agricultural practice.

\section{Cotton Industry in Northern Nigeria}

AN interesting account of the future possibilities of the cotton industry in Nigeria was given by Mr. G. Browne, manager of the English Cotton Growing Corporation's Seed Farm in Northern Nigeria, at a recent meeting of the Administrative Council. The farm was started ten years ago, and has been chiefly occupied with testing out new strains of cotton prior to their distribution to the native farmers. In addition, a study has been made of intercropping with some plant other than cotton, the evidence going to show that better results are secured if two crops follow each other instead of being grown almost simultaneously. The question of the maintenance of fertility inevitably arises with this practice, and as green manuring proved unsuccessful, an entirely new method, namely, the introduction of cattle, was tried.
At first high mortality rates occurred, due partly to tsetse fly trouble and partly to lack of experience as to the conditions under which cattle can be kept in good health in this district. Now, however, that the preliminary difficulties have been overcome by bush clearance and regular use of dip, etc., the cattle are already playing an important part in the agriculture of Northern Nigeria, and a new era of expansion seems probable. New implements, notably a steel plough, have also been introduced, and further, the Corporation is hoping, by the example of its own farm as well as by other means, to aid in this future development of the agricultural industry in Northern Nigeria, of which an increased output of cotton should be an outstanding result.

\section{Dialling Ships at Sea}

WHEN the radio telephone was first applied to ships at sea about 1929 , the ship receivers, connected either to a loud speaker or an operator's headset, were always 'on the air' and thus heard all calls. Stations were called by name, and all other stations listening on the same frequency would hear the call. With the increasing use of ship to shore radio service, a method of signalling one ship only became highly desirable, as this would obviate the necessity of keeping the loud speakers or telephone receivers 'on the air' all the time. In the Bell Laboratories Record of April a method of doing this is described. With this system, each ship has a three digit number assigned to it. When the operator at the telephone switchboard wishes to place a call, he merely dials the number of the ship wanted. This sends out a series of tone pulses which are received by all the ships within range. The called ship is the only one that receives an audible signal. On this ship a telephone bell rings and the operator picks his handset off the hook and replies in the usual way. When a call is answered, the handset is removed from its switchhook, thus operating the transfer relay. This removes the selector set from the radio receiver and connects the telephone receiver in its place. It also stops the bell ringing. When the telephone conversation is finished, the handset is returned to its hook and this releases the relay. The signal receiving set is automatically reconnected in preparation for receiving calls. This system is now being used by a number of coasting and harbour ships in America, but it promises to become applicable to a much wider field.

\section{Meteorology and the Sea Service}

THE Marine Observer of April (13, No. 122) contains an article by Capt. L. A. Brooke-Smith, superintendent of the Marine Division of the Meteorological Office, Air Ministry, entitled "Observation and Weather Forecasting and Some of their Bearings on the Sea Service". The author comments on the great improvement in accuracy of observations of barometric pressure at sea since the Great War, and attributes this to the growing realisation on the part of ships' officers that weather forecasting is not only possible by a few specially trained meteorologists in observatories ashore, and to the increasingly 